\title{
Measured and predicted temperatures in a grain processing building under heat treatment -2 . Mathematical modeling of heat and mass transfer during heat treatment
}

\author{
F. Jian ${ }^{1}$, P.G. Fields ${ }^{2}$, D.S. Jayas ${ }^{1 *}$, N.D.G. White ${ }^{2}$ and M. Loganathan ${ }^{1,3}$ \\ ${ }^{I}$ Department of Biosystems Engineering, University of Manitoba, Winnipeg, MB, R3T 5V6, Canada; \\ ${ }^{2}$ Agriculture and Agri-Food Canada, Cereal Research Centre, 195 Dafoe Road, Winnipeg, MB, R3T 2M9, Canada; and \\ ${ }_{3}^{3}$ Indian Institute of Crop Processing Technology, Ministry of Food Processing Industries, Government of India, \\ Pudukkottai Road, Thanjavur 613 005, India. \\ *Email:Digvir_jayas@umanitoba.ca
}

Jian, F., P.G. Fields, D.S. Jayas, N.D.G. White and M. Loganathan. 2012. Measured and predicted temperatures in a grain processing building under heat treatment -2 . Mathematical modeling of heat and mass transfer during heat treatment. Canadian Biosystems Engineering/Le génie des biosystèmes au Canada 54:3.93.17. Heat treatment to control pest insects in grain processing facilities is becoming more widely used because the fumigant methyl bromide has generally been phased out due to its atmosphere ozone-depleting characteristics. Models with finite difference method, using realistic boundary conditions, were developed to predict the heat and mass transfer that occurred on a concrete floor, in the presence and absence of grain, inside a heattreated building. Temperatures measured every $2 \mathrm{~min}$ at $0.5 \mathrm{~m}$ below the ceiling and $0.05 \mathrm{~m}$ above the bare concrete floor and room relative humidity $(\mathrm{RH})$ were used to model temperature and water loss inside wheat and oats. Temperatures on the surface of the concrete floor and in the grain measured every 2 min during the heat treatment were used to verify and validate the developed models. The maximum and minimum residues between the measured and predicted temperatures of the concrete floors under grain were $3.2^{\circ} \mathrm{C}$ and $-2.8^{\circ} \mathrm{C}$, respectively. The larger residues were mostly located at the beginning of the heat treatment. After concrete floor temperatures reached $25^{\circ} \mathrm{C}$, the residues between the measured and calculated temperatures of concrete floors under grain were less than $\pm 1^{\circ} \mathrm{C}$. These residues were also less than the differences between the temperatures measured in different replicates.

The temperature of concrete floor was simulated under the following assumptions: 1) continuous heating of the building for $36 \mathrm{~h}$; and 2) wheat and oats at $11.0,13.0$, or $15.0 \%$ moisture contents with $0.01,0.05$, or $0.10 \mathrm{~m}$ thickness evenly covering a $0.35 \mathrm{~m}$ diameter area on the concrete floor. Simulation results showed that: 1) the temperature of the concrete floor could reach $50^{\circ} \mathrm{C}$ after $30 \mathrm{~h}$ heat treatment; 2) moisture content of the grain could make about $2.5^{\circ} \mathrm{C}$ difference to the concrete floor temperature; and 3) cleaning before heat treatments should be sufficient to have residues of no more than $0.01 \mathrm{~m}$ thick of grain or grain products on floors. Kew words: Heat treatment, grainprocessing building, temperature, mathematical modeling.
Le traitement thermique pour contrôler les insectes nuisibles dans les installations de transformation des céréales est de plus en plus utilisé car la fumigation au bromure de méthyle se voit progressivement abandonnée en raison de son potentiel à endommager l'ozone atmosphérique. Des modèles utilisent une méthode aux différences limitées, et des conditions aux limites réalistes, ont été développés pour prédire le transfert de chaleur et de masse qui s'est produit sur un plancher de béton, avec et sans céréales, à l'intérieur d'un bâtiment, pendant un traitement thermique. Les températures mesurées toutes les 2 minutes à 0,5 $\mathrm{m}$ en dessous du plafond et à $0,05 \mathrm{~m}$ au-dessus du plancher nu en béton et l'humidité relative de la salle ont été utilisés pour faire un modèle de la température et de la perte d'eau dans le blé et l'avoine. Les températures sur la surface du plancher de béton et dans le grain mesurées toutes les 2 minutes pendant le traitement thermique ont été utilisées pour vérifier et valider les modèles développés. Les résidus entre les températures mesurées et les prévisions pour les planchers de béton sous des céréales avaient un maximum de $3,2{ }^{\circ} \mathrm{C}$ et un minimum de $-2,8{ }^{\circ} \mathrm{C}$, respectivement. Les résidus les plus grands se trouvaient surtout au début du traitement thermique. Après que les températures au plancher en béton ont atteint $25^{\circ} \mathrm{C}$, les résidus entre les températures mesurées et celles calculées pour les planchers de béton sous des céréales étaient inférieures à $\pm 1{ }^{\circ} \mathrm{C}$. Ces résidus étaient également inférieurs à la différence entre les températures mesurées dans les divers endroits.

La température du béton a été simulée selon les conditions suivantes: 1) le chauffage de l'immeuble continue pendant 36 heures et 2) le blé et l'avoine à $11,0,13,0$, ou 15,0\% de teneur en eau avec $0,01,0,05$, ou $0.10 \mathrm{~m}$ d'épaisseur couvrant de façon uniforme une zone de diamètre de $0,35 \mathrm{~m}$ sur le plancher de béton. Les résultats de simulation ont montré que: 1) la température du plancher de béton pourrait atteindre $50{ }^{\circ} \mathrm{C}$ après 30 heures de traitement thermique, 2) la teneur en eau du grain pourrait faire varier la température du plancher en béton, de 2,5 ${ }^{\circ} \mathrm{C}$ et 3) le nettoyage avant les traitements thermiques doit être suffisant pour maintenir les résidus de grain inférieurs à $0,01 \mathrm{~m}$ d'épaisseur de grain ou de produits de grain sur le plancher. Mots clés: traitement thermique, installations de transformation des céréales, température, modèles mathématiques. 


\section{INTRODUCTION}

In Part 1 of this study (Jian et al. 2012), air, grain, and concrete floor temperatures were measured in a flourmill storage building during heat treatment. The concrete floor was the coldest spot, and the vicinity temperature and grain covering influenced the temperature. The vicinity temperature mainly influenced the temperature increase rate at the grain surface. After the surface grain temperature reached $97 \%$ of its maximum temperature, it would be influenced by the vicinity temperature and periphery configurations (flat or sloped surface in tubes or piles, respectively). Increasing grain depth on the concrete floor would decrease the temperature on the concrete floor.

\section{Ceiling}

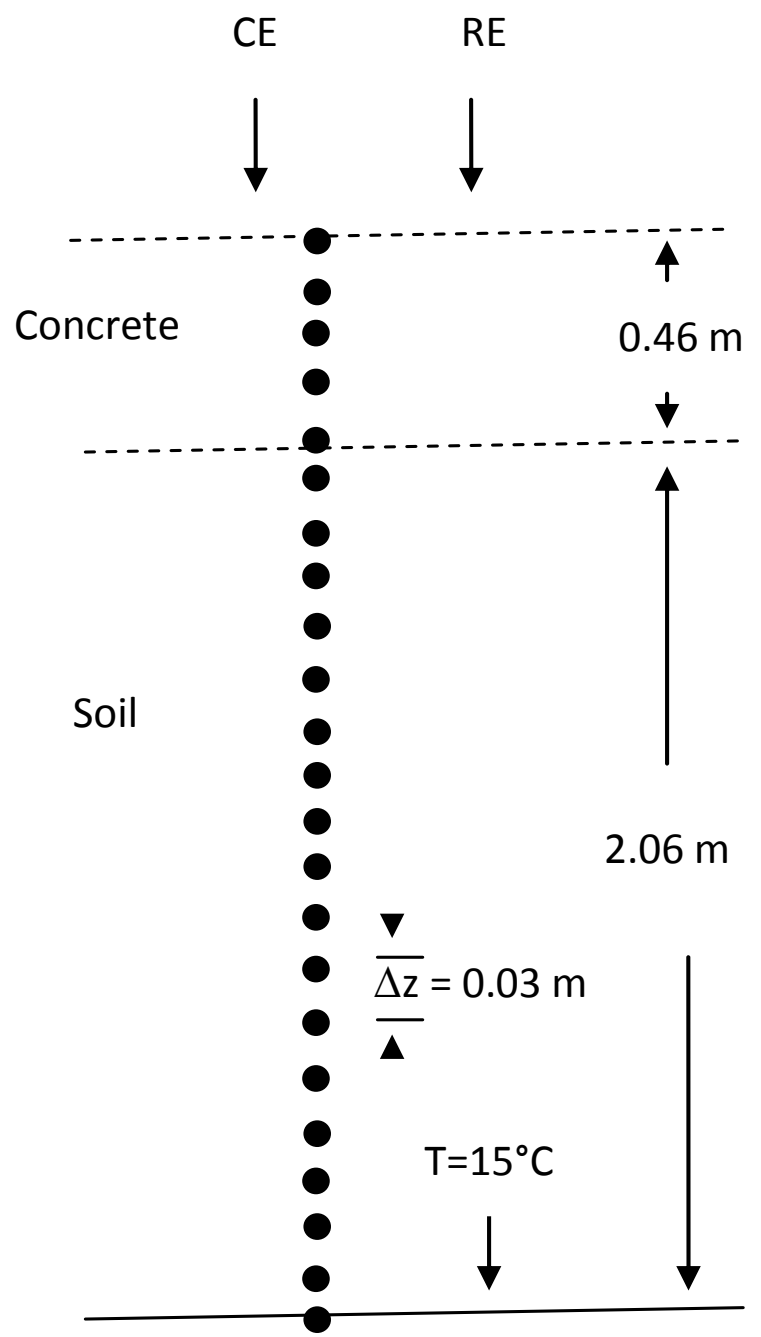

Fig. 1 Finite-difference grid and energy balance at the surface of the concrete, there were 15 and 68 nodes in the concrete and soil layers, respectively. $\mathrm{CE}=$ convective energy fluxes. $\mathrm{Re}$ $=$ radiation heat fluxes.
Based on the theory of heat and mass transfer (Arpaci and Larsen 1984; Thomas 1980), the grain and concrete temperature should be affected by the following factors: type and intensity of heating system, placement of heat sources, number of fans to facilitate air movement, placement of fans, dimensions of the room, equipment present in the room, outside ambient temperature, structure of the building, thickness of and construction materials of the floor, thermal property and thickness of the grain and building materials, moisture contents of the grain, surface configuration of the grain mass, and air velocity on the surface of the grain mass. The effects of these factors could be determined experimentally. Such a study would require several buildings at several locations for several years. Moreover, determining the individual effects of even one factor, such as concrete thickness, could require at least three buildings ranging in thickness from 0 to a given maximum thickness. To separate the effect of building structure, the study would have to be conducted over several different buildings. Such an experimental approach is neither practical nor economical. A more rapid and less expensive approach is to develop a mathematical model and verify and validate the model with a few experimental studies (Jayas 1995). Mathematical simulations using computers are less accurate than actual tests, but by calibrating and validating the developed models, their accuracy can be verified and improved. The effects of individual factors can be isolated in simulation models by changing only one factor at a time. There are no published mathematical models to calculate the concrete floor temperature during a heat treatment.

The aim of this study was: 1) to develop finite difference models to predict the temperatures of concrete floors with or without grain; 2) verify and validate the developed models using the measured temperatures in part I of this study (Jian et al. 2012); and 3) to predict floor temperature under different assumptions.

\section{MODEL DEVELOPMENT}

\section{Basic assumptions}

To calculate the temperature of the grain or concrete, the following assumptions were made:

(1) The thickness of the concrete floor was $0.46 \mathrm{~m}$. The temperature of the soil at the depth of $2.52 \mathrm{~m}$ was constant during the heat treatment (Figs. 1 and 2).

(2) The grain, concrete, and soil had uniform thermal properties (Table 1).

(3) There was no moisture migration inside the concrete and soil during the heat treatment.

(4) There was no evaporation on the concrete surface.

(5) There was no heat generated but only conducted inside the grain, concrete, and soil. This conduction heat could be described by the following two-dimensional and transient heat conduction equation:

$$
\frac{\partial T^{2}(x, t)}{\partial x^{2}}+\frac{\partial T^{2}(z, t)}{\partial z^{2}}=\frac{1}{\alpha} \frac{\partial T(x, z, t)}{\partial t}
$$

where: 
Table 1. Thermal properties of materials

\begin{tabular}{lcccc}
\hline & Wheat & Oats & Concrete & Soil \\
\hline Conductivity $(\mathrm{W} / \mathrm{m} \cdot \mathrm{K})$ & $0.16^{[\mathrm{a}]}$ & $0.13^{[\mathrm{a}]}$ & $2.19^{[\mathrm{b}]}$ & $2.00^{[\mathrm{b}]}$ \\
Density $\left(\mathrm{kg} / \mathrm{m}^{3}\right)$ & $750^{[\mathrm{a}]}$ & $412^{[\mathrm{a}]}$ & $2252^{[\mathrm{b}]}$ & $800^{[\mathrm{b}]}$ \\
Diffusivity $\left(10^{-8} \times \mathrm{m}^{2} / \mathrm{s}\right)$ & $11.90^{[\mathrm{a}]}$ & $24.70^{[\mathrm{a}]}$ & $0.24^{[\mathrm{b}]}$ & $62.51^{[\mathrm{b}]}$ \\
Emissivity & $0.80^{[\mathrm{c}]}$ & $0.85^{[\mathrm{b}]}$ & \\
\hline
\end{tabular}

[a] Source: ASABE, 2009.

${ }^{[b]}$ Source: Krarti and Clarid 1988.

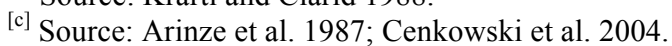

${ }^{[d]}$ source: Arinze et al. 1987; Massie and Norris 1965.

$$
\begin{aligned}
\mathrm{T}= & \text { temperature of the materials }\left({ }^{\circ} \mathrm{C}\right), \\
\mathrm{t}= & \text { time }(\mathrm{s}), \\
\mathrm{z}= & \text { depth of the grain, concrete, and soil in the vertical } \\
& \text { direction }(\mathrm{z}=0 \text { at the surface of the floor or grain } \\
& \text { mass })(\mathrm{m}), \\
\mathrm{x}= & \text { distance between two measured temperature } \\
& \text { locations in the horizontal direction }(\mathrm{m}), \text { and } \\
\alpha= & \text { thermal diffusivity of the materials } \\
& (\text { Table } 1)\left(\mathrm{m}^{2} / \mathrm{s}\right) .
\end{aligned}
$$

\section{Ceiling}

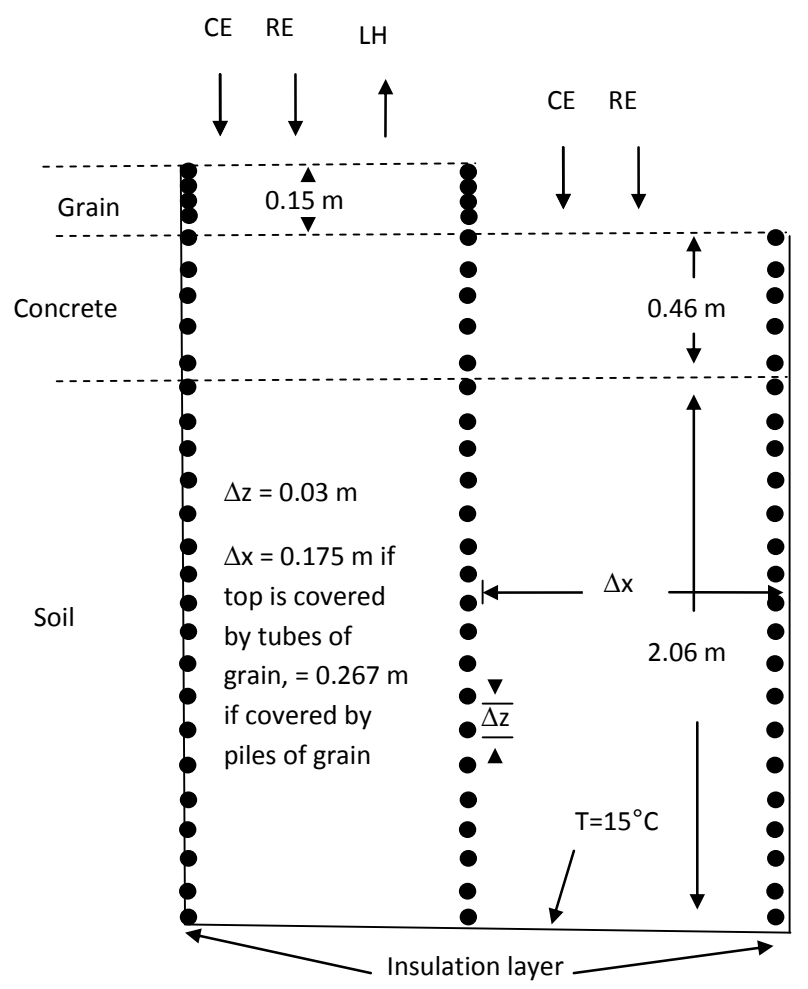

Fig. 2 Finite-difference grid and energy balance at the surface of the grain. At one location and in the vertical direction, there were 5,15 , and 68 nodes in the grain, concrete, and soil layers, respectively. $\mathrm{CE}=$ convective energy fluxes. $\mathrm{Re}=$ radiation heat fluxes. $\mathrm{LH}=$ latent heat fluxes due to evaporation.
(6) The energy balance on the surface of the grain was:

$$
-\frac{k_{g} \partial T_{s}}{\partial z}=C E+R E-L H \quad \text { at } z=0
$$

where:

$\mathrm{k}_{\mathrm{g}}=$ thermal conductivity of the grain $\left(\mathrm{W} / \mathrm{m}{ }^{\circ} \mathrm{C}\right)$,

$\mathrm{T}_{\mathrm{s}}=$ temperature on the grain surface $\left({ }^{\circ} \mathrm{C}\right)$,

$\mathrm{CE}=$ convective energy exchange between air and the grain surface $\left(\mathrm{W} / \mathrm{m}^{2}\right)$,

$\mathrm{RE}=$ radiation energy exchange between the building ceiling and the grain surface $\left(\mathrm{W} / \mathrm{m}^{2}\right)$, and

$\mathrm{LE}=$ latent heat exchange between the grain and the air $\left(\mathrm{W} / \mathrm{m}^{2}\right)$.

\section{Convective energy fluxes}

The hydrodynamic properties of the heat-treated air were determined by calculating the Reynolds number (Arpaci and Larsen 1984).

$$
R e=\frac{U_{\infty} L}{v}
$$

where:

$U_{\infty}=$ air velocity $(\mathrm{m} / \mathrm{s})$. The fan generated 3.7 to 6.7 $\mathrm{m} / \mathrm{s}$ at the experimental location,

$\mathrm{L}=$ length from the fan to the pile of the grains (14.6 $\mathrm{m})$, and

$v=$ kinematic viscosity of the air $\left(\mathrm{m}^{2} / \mathrm{s}\right)$ and was calculated as:

$$
v=\left(\frac{5.08}{50}\left(T_{\infty}-300\right)+15.68\right) 10^{-6}
$$

where:

$T_{\infty}=$ measured air temperature at $0.05 \mathrm{~m}$ above the concrete floor $\left({ }^{\circ} \mathrm{C}\right)$

$\mathrm{Re}=$ Reynolds number and was from $3.6 \times 106$ to $6.5 \times 106$.

Therefore, the flow was fully turbulent (Arpaci and Larsen 1984). The average convective coefficient of the heat transfer at the concrete or grain surface was calculated as:

$$
\bar{h}=0.0369 \operatorname{Re}^{0.8} \operatorname{Pr}^{0.5} \frac{k_{a}}{L}
$$

where:

$$
\begin{aligned}
\bar{h}= & \text { average convective coefficient of the heat transfer } \\
& \text { at the concrete or grain surface }\left(\mathrm{W} /\left(\mathrm{m} 2 \bullet{ }^{\circ} \mathrm{C}\right)\right. \\
\operatorname{Pr}= & \text { Prandtl number }(0.708) \\
\mathrm{k}_{\mathrm{a}}= & \text { the thermal conductivity of the air }\left(\mathrm{W} /\left(\mathrm{m}{ }^{\circ} \mathrm{C}\right)\right) \\
& \text { and was calculated as: }
\end{aligned}
$$




$$
k_{a}=\frac{0.00379}{50}\left(T_{\infty}-300\right)+0.02624
$$

The convective exchange fluxes (CE) between the heattreated air and the concrete or grain surface was calculated as:

$$
C E=\bar{h}\left(T_{s}-T_{\infty}\right)
$$

\section{Radiation heat fluxes}

Christiansen formula (Thomas 1980) was used to calculate the irradiative heat exchange between the surface of the floor or grain mass and the ceiling of the building:

$$
E R=\frac{\sigma\left(T_{C}^{4}-T_{S}^{4}\right)}{\varepsilon_{c}^{-1}+\varepsilon_{s}^{-1}-1}
$$

where:

$\sigma=$ Stefan-Boltzmann constant $[5.670 \times 10-8 \mathrm{~W} /(\mathrm{m} 2$ $\mathrm{K} 4)$ ],

$\mathrm{T}_{\mathrm{c}}=$ temperature of the building ceiling $(\mathrm{K})$,

$\varepsilon_{\mathrm{c}}=$ emissivity of the building ceiling (metal with white paint, 0.88), and

$\varepsilon_{\mathrm{s}}=$ emissivity of the floor (Table 1).

\section{Latent heat fluxes due to evaporation}

The latent heat fluxes were calculated after Bala (1997):

$$
\begin{aligned}
& \frac{L_{g}}{L_{\text {water }}}=1+23 e^{-0.4 M_{d}} \quad \text { wheat } \\
& \frac{L_{g}}{L_{\text {water }}}=1+0.5953 e^{-0.1367 M_{d}} \quad \text { oats }
\end{aligned}
$$

where:

$\mathrm{L}_{\mathrm{g}}=$ the latent heat of the grain $(\mathrm{J} / \mathrm{kg})$,

$\mathrm{M}_{\mathrm{d}}=$ the grain moisture content (dry basis, decimal), and

$\mathrm{L}_{\text {water }}=$ the latent heat of free water $(\mathrm{KJ} / \mathrm{kg})$.

$\mathrm{L}_{\text {water }}$ was calculated by using the following equation (Thorpe 2002):

$$
L_{\text {water }}=2501.33-2.363 T
$$

where:

$\mathrm{T}=$ the grain temperature $\left({ }^{\circ} \mathrm{C}\right)$.

The total latent heat fluxes were calculated by:

$$
L H=L_{g} \frac{d M}{d t}
$$

where:

$\mathrm{dM} / \mathrm{dt}=$ the mass of evaporated water from the grain $(\mathrm{kg} / \mathrm{s})$.

\section{Mass of evaporated water at surface of the grain}

It was assumed that the grain at the surface (the top $0.01 \mathrm{~m}$ grain) experienced a thin layer drying process. The mass of the evaporated water at this top layer was determined after Page (1949):

$$
\frac{M(0, t)-M_{e}}{M_{0}-M_{e}}=\exp \left(-K t^{N}\right)
$$

For wheat (Sinicio et al. 1995):

$K=$

$$
\begin{aligned}
& 0.6348 \times 10^{-6} \exp (0.03733 T)\left(M_{0}-M_{e}\right)^{0.1824 R H^{-0.6724}} \\
& \qquad \begin{array}{l}
\quad N=1.13 M_{0}^{0.3225} \\
\text { For oats (Bruce } 1985) \text { : } \\
\qquad K=0.0462 \times 10^{-6} \exp (0.0154 T) \\
\quad N=0.492+3.84 \times 10^{-5}(T-123)^{2}
\end{array}
\end{aligned}
$$

where:

$\mathrm{M}(0, \mathrm{t})=$ moisture content of the top layer at time $\mathrm{t}, \mathrm{db}$,

$\mathrm{M}_{\mathrm{e}}=$ equilibrium moisture content, $\mathrm{db}$,

$\mathrm{M}_{0}=$ initial moisture content, $\mathrm{db}$,

\begin{tabular}{|c|c|c|c|c|c|}
\hline Periphery configuration & Materials & Replicate & Mean $\pm \mathrm{SE}$ & Maximum & Minimum \\
\hline \multirow{3}{*}{ Tube } & Wheat & R1 & $1.2 \pm 0.1$ & 3.2 & -1.6 \\
\hline & & R2 & $1.5 \pm 0.1$ & 3.1 & -1.3 \\
\hline & & R3 & $1.0 \pm 0.1$ & 2.9 & -1.7 \\
\hline \multirow{9}{*}{ Pile } & Oats & R1 & $0.7 \pm 0.0$ & 1.8 & -1.1 \\
\hline & & R2 & $0.2 \pm 0.0$ & 1.5 & -1.8 \\
\hline & & R3 & $0.9 \pm 0.0$ & 1.9 & -1.5 \\
\hline & Wheat & R1 & $0.8 \pm 0.1$ & 2.5 & -1.8 \\
\hline & & R2 & $0.1 \pm 0.1$ & 2.3 & -2.4 \\
\hline & & R3 & $-0.1 \pm 0.1$ & 2.4 & -2.3 \\
\hline & Oats & R1 & $0.4 \pm 0.1$ & 2.1 & -1.5 \\
\hline & & R2 & $-0.6 \pm 0.1$ & 2.2 & -3.2 \\
\hline & & $\mathrm{R} 3$ & $0.5 \pm 0.1$ & 2.9 & -2.8 \\
\hline
\end{tabular}

$\mathrm{T}=$ grain temperature $(\mathrm{K})$, and

$\mathrm{RH}=$ relative humidity $(30 \%)$.

The equilibrium moisture content $(\mathrm{Me})$ was calculated using the Chung equation (ASABE 2009).

$$
\begin{array}{r}
M_{e}=0.35616-0.056788 \ln [-(T+50.998) \ln (R H)] \\
\text { wheat }(18) \\
M_{e}=0.33363-0.050279 \ln [-(T+91.323) \ln (R H)] \\
\text { oats } \quad(19)
\end{array}
$$

During model evaluation and verification, it was found that:1) the drying rate of the thin layer increased with increasing air temperature, but it is independent of air flow rate (Bala 1997); and 2) this thin layer drying model overpredicted the water loss at the surface of the grain mass by

Table 2. Residues $\left({ }^{\circ} \mathrm{C}\right)$ between measured and predicted temperatures of concrete floors under grains. 


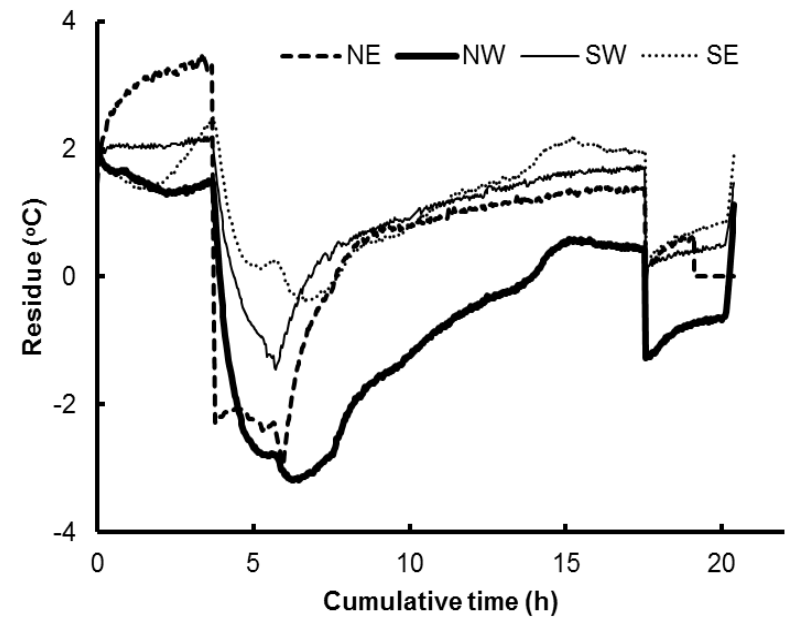

Fig.3. Residues between the measured and predicted temperatures on a concrete floor without grain covering at the North-East (NE), North-West (NW), South-East (SE), and South-West (SW) locations.

$20 \%$. Therefore, the mass of evaporated water calculated using Eq. 13 was modified by a constant of 0.8 .

\section{Mass of water lost inside grain mass}

The grain under the top layer might lose water via diffusion. The mass diffusivity of the water inside the grain bulk was calculated after Crank (1975):

$\frac{M(z, t)-M_{e}}{M_{0}-M_{e}}=\frac{4}{\pi} \sum_{\mathrm{n}=0}^{\infty} \frac{(-1)^{\mathrm{n}}}{2 \mathrm{n}+1} \cos \frac{(2 \mathrm{n}+1) \pi \mathrm{z}}{2 \mathrm{~s}} \exp \left(-\frac{\pi^{2}(2 n+1)^{2}}{4} \frac{D_{m} t}{s^{2}}\right)$

where;

$\mathrm{S}=$ total thickness of the grain mass $(\mathrm{m})$, and

$D_{m}=$ coefficient of diffusion ( $\left.2 / \mathrm{s}\right)$.

To find the coefficient of diffusion, about $15 \mathrm{~kg}$ wheat and oats (the same grain as used in the heat treatment experiment) were put in metal tubes [the same as in Fig. 1 of Part I in this study (Jian et al. 2012)]. The bottom of the tube was set on $0.35 \mathrm{~m}$ Styrofoam. This grain was put in an oven at $60^{\circ} \mathrm{C}$. After $20 \mathrm{~h}$, moisture content of the grain at $0.0,0.03,0.06,0.09,0.12$, and $0.15 \mathrm{~m}$ below the grain surface was measured. Grain at $0.06 \mathrm{~m}$ or lower did not lose moisture.

$\mathrm{A} \mathrm{C}^{++}$program was coded and the least square method was used to find the $\mathrm{D}_{\mathrm{m}}$. The coefficient of diffusion of the water inside the wheat and oats at 0.03 to $0.06 \mathrm{~m}$ deep was $(1.1563 \pm 0.9877) \times 10-8$ and $(7.8625 \pm 0.67165) \times 10-9 \mathrm{~m} 2 / \mathrm{s}$, respectively.

\section{Method of solution}

Finite difference method was used to find the temperature at the surface of the concrete floor or grain and inside the grain, concrete, and soil (Thomas 1980; Acs et al. 1991). The grain, concrete and soil were split into equal elements of depth $\Delta z$ (Figs. 1 and 2). At the place without grain, the

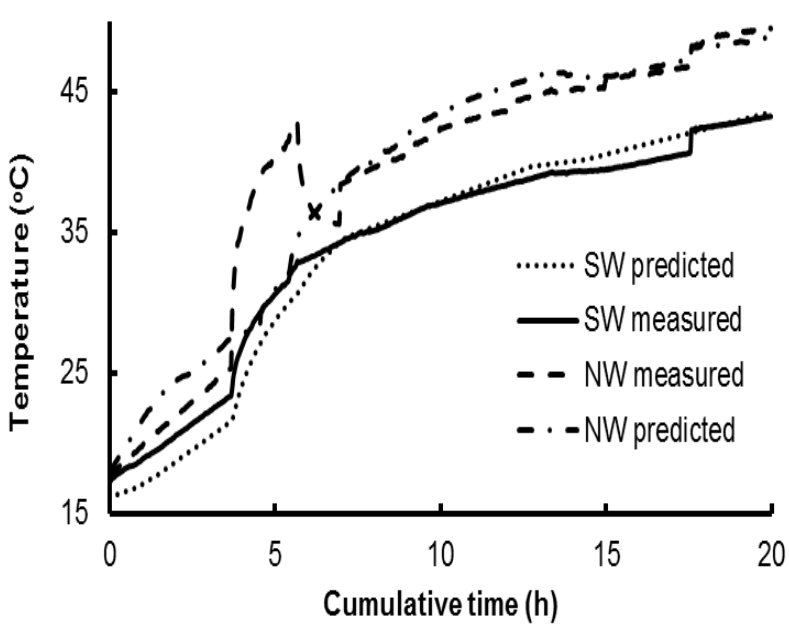

Fig. 4. Measured and predicted temperature of a concrete floor without grain at the South-West (SW) and North-West (NW) locations.

grain did not influence the temperatures of the concrete and soil. Therefore, the temperatures of the concrete and soil without grain were solved using one dimensional finite difference method (Fig. 1). At the place with grain, the nearby concrete and soil temperatures influenced the grain temperatures. The temperatures of the grain, concrete, and soil were calculated using two-dimensional finite difference method (Fig. 2).

\section{Data analysis}

The measured temperatures (Jian et al. 2012) at the concrete surface, middle of the grain piles or tubes, and the surface of the grain mass were compared with the temperatures predicted by the developed models. The residues between measured and predicted temperatures were used to verify and validate the developed models.

\section{RESULTS AND DISCUSSION}

\section{Floor temperatures without grain}

At the four corners of the experimental location, the model over-predicted the bare concrete temperatures from 0 to $4.2 \mathrm{~h}$ and from 13.5 to $17.5 \mathrm{~h}$ of the cumulative heat treatment time. The model under-predicted the bare concrete temperatures from 5.8 to $6.0 \mathrm{~h}$ of the cumulative heat treatment time (Figs. 3 and 4). The maximum of overand under-predicted temperatures were 3.5 and $-3.2{ }^{\circ} \mathrm{C}$, respectively. This over-prediction was mainly caused by the fluctuation of the measured concrete temperatures due to the air circulating fans being repositioned at 4.2 and $17.5 \mathrm{~h}$ of the cumulative heat treatment time. However, the calculated temperatures did not over-or under-predict the highest temperatures (Figs. 3 and 4).

\section{Floor temperatures under grain}

The maximum and minimum residues between the measured and calculated temperatures of the concrete 

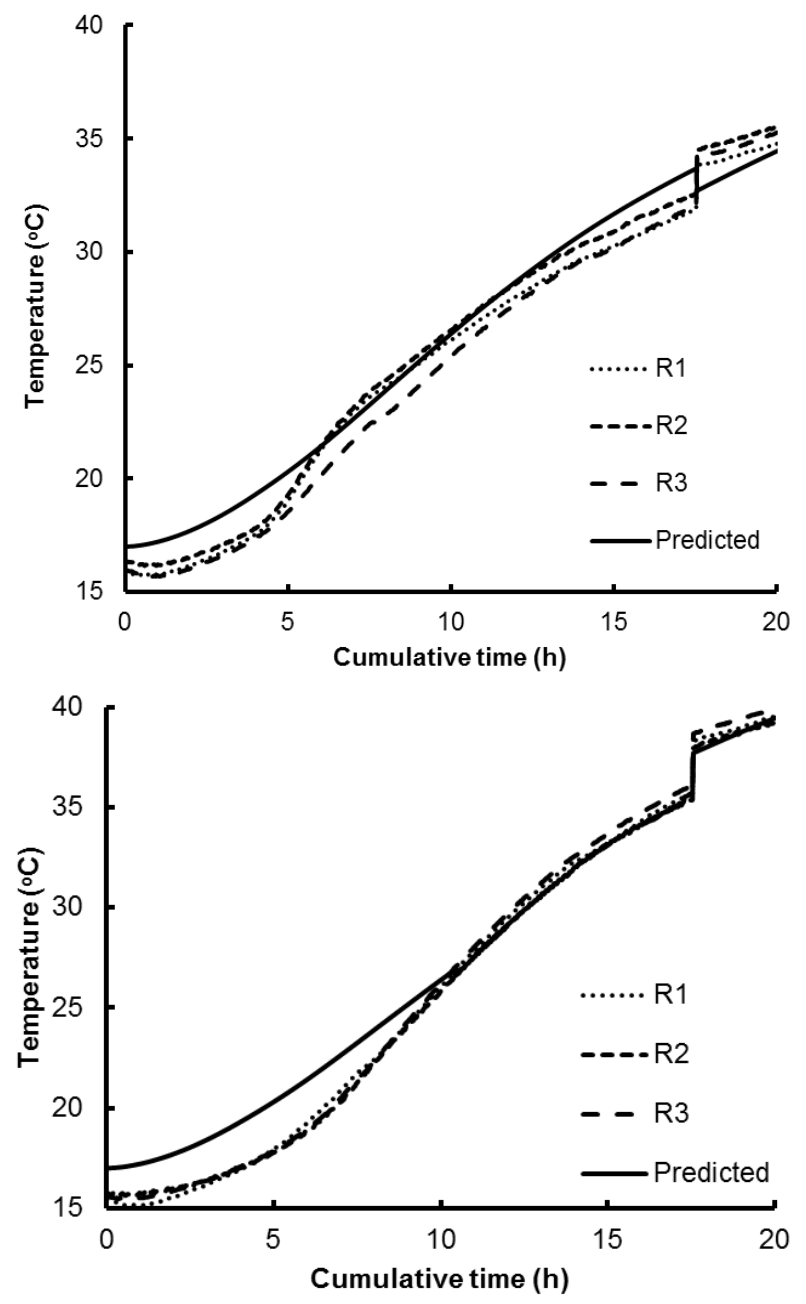

Fig.5 Measured and predicted temperature on a concrete floor under wheat (top) and oats (bottom) inside tubes. In the graph, R1, R2, and $\mathrm{R} 3$ are the measured temperatures in replicates 1,2 and 3.

floors under grain were 3.2 and $-2.8^{\circ} \mathrm{C}$ (Table 2). The mean residue at all the measured locations was less than $1.5 \pm 0.1^{\circ} \mathrm{C}$. The larger residues mostly occurred at the beginning of the heat treatment time (Fig. 5). After the concrete floor temperature reached $25^{\circ} \mathrm{C}$, the residues between the measured and calculated temperatures of concrete floors under grain covering was less than $\pm 1^{\circ} \mathrm{C}$. Therefore, the developed model could be used to predict the temperature of the concrete floor with or without grain.

\section{Grain temperatures}

The developed model did not over- or under-predict the surface temperature of the grain mass inside tubes or piles (Figs. 6 and 7). The maximum and minimum residues between the measured and calculated temperatures of the surface of the grain mass inside tubes were $6.7^{\circ} \mathrm{C}$ and $5.9^{\circ} \mathrm{C}$ (Fig. 6). The mean residue was less than $2.2 \pm 0.1^{\circ} \mathrm{C}$. The maximum and minimum residues between the measured and calculated temperatures of the surface of the
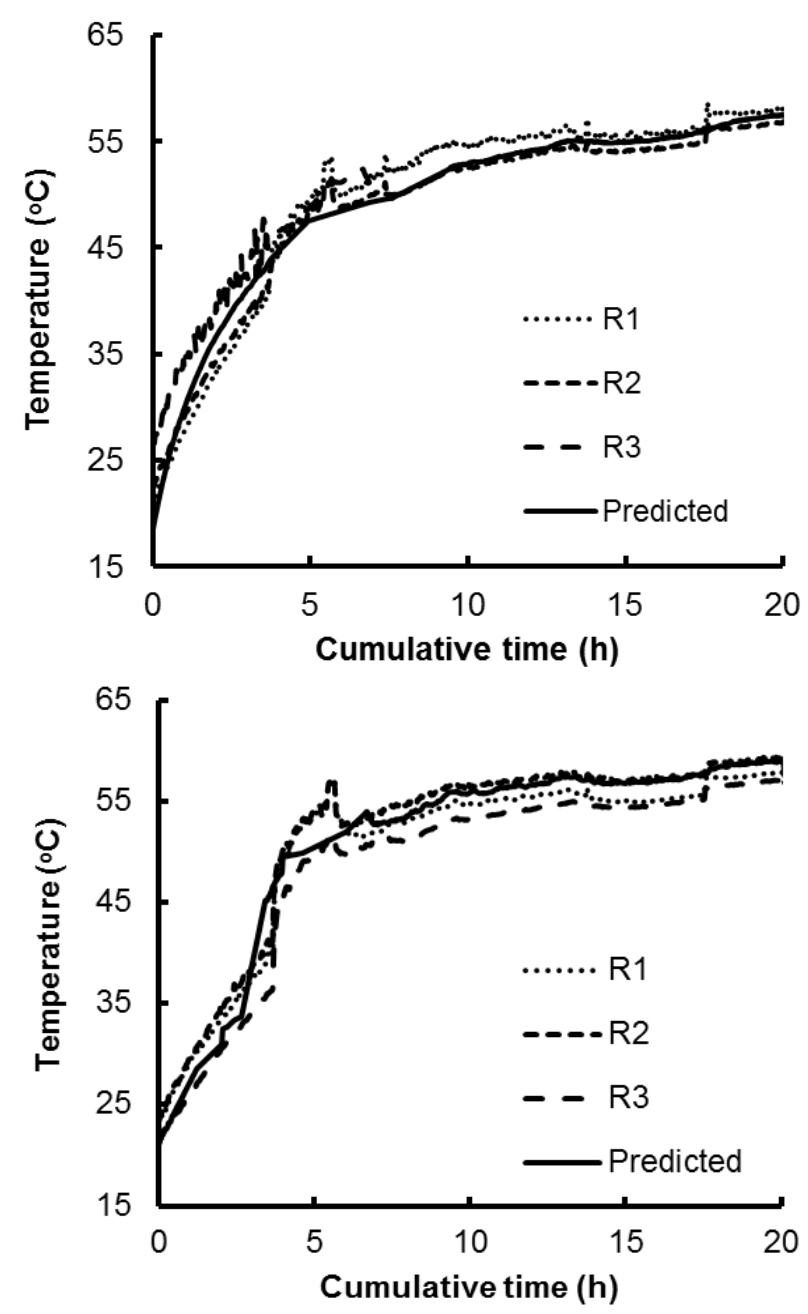

Fig. 6 Measured and predicted temperatures at the surface of the grain mass of wheat (top) and oats (bottom) inside the grain tubes. In the graph, R1, R2, and $\mathrm{R3}$ are the measured temperatures in replicates 1,2 and 3.

grain mass inside piles were $5.1{ }^{\circ} \mathrm{C}$ and $-6.0^{\circ} \mathrm{C}$ (Fig. 7). The mean residue was less than $2.2 \pm 0.1{ }^{\circ} \mathrm{C}$. These residues were less than the differences between the temperatures measured in different replicates (Figs. 6 and 7). The residues between measured and predicted grain temperatures in the middle of tubes and piles were less than that at the surface of the grain mass in tubes and piles. Therefore, the developed model could be used to predict the temperature of the grain mass during heat treatment.

\section{Simulation}

Concrete floor without grain covering To verify if the bare concrete floor in this heat-treated building can be heated up to $50^{\circ} \mathrm{C}$, the following assumptions were made: 1) continuous supply of heat to the building; 2) maintenance of the ceiling temperature at less than $65^{\circ} \mathrm{C}$; 3) maximum heat treatment time period of $36 \mathrm{~h}$; and 4) the configuration at North-East locations was the configuration inside the simulation building. It was found 

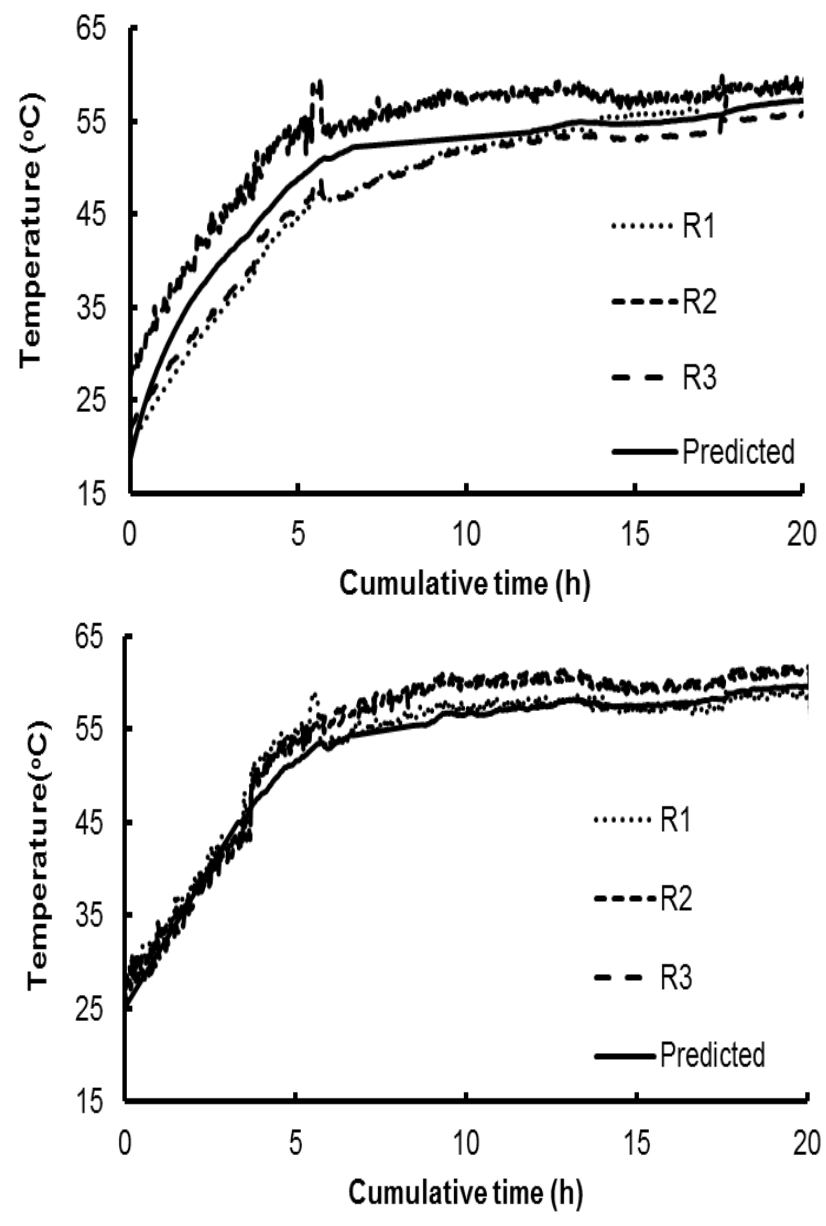

Fig. 7 Measured and predicted temperatures at the surface of the grain mass of wheat (top) and oats (bottom) inside the middle of grain piles. In the graph, R1, R2, and R3 are the measured temperatures in replicates 1,2 and 3.

that approximately $30 \mathrm{~h}$ was required to heat the bare concrete floor up to $50^{\circ} \mathrm{C}$ (Fig. 8). At $36 \mathrm{~h}$, the bare concrete temperature was $50.5^{\circ} \mathrm{C}$. The developed model was not $100 \%$ accurate, and $8 \mathrm{~h}$ are required to control the larvae of T. Castaneum. Therefore, to successfully kill all insects on the bare concrete floor, this building should be heat-treated for at least $40 \mathrm{~h}$ or it should be ensured that heat be redirected to colder floor areas.

Thickness of the grain covering To determine whether a thin layer of grain on concrete floors will attain a temperature sufficient to kill insects, the following assumptions were made: 1 ) wheat and oats with $0.01,0.05$, and $0.10 \mathrm{~m}$ thickness evenly covered a $0.35 \mathrm{~m}$ diameter area on the concrete floor; 2) the initial grain moisture content of the grain was $11.0,13.0$, and $15.0 \%$; and 3 ) the configuration at the North-East location was the configuration inside the simulation building. Simulation results revealed that: 1) there were no differences due to the same thickness of oats and wheat; 2) moisture content of the grain could make about a $2.5^{\circ} \mathrm{C}$ difference to the concrete floor temperature (Fig. 9); and 3) thickness of the

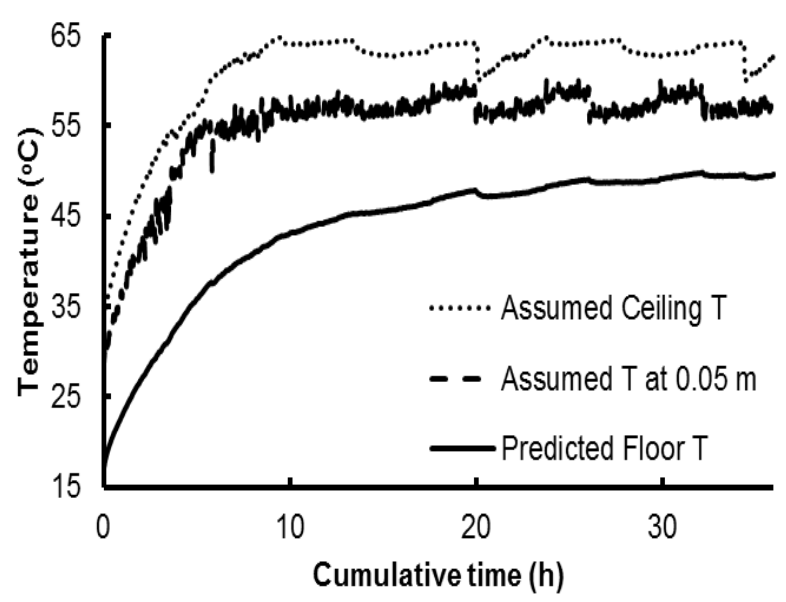

Fig. 8. Simulated temperature of the bare concrete floor at North-East location of the experimental location (Predicted Floor T). The "Assumed Ceiling T" and "Assumed $\mathrm{T}$ at $\mathbf{0 . 0 5}$ m" were created by: 1) from 0 to $20 \mathrm{~h}$ of the cumulative time of the heat treatment, using the measured temperatures at the $0.5 \mathrm{~m}$ below ceiling and $0.05 \mathrm{~m}$ above the floor respectively; and 2) from 20 to $36 \mathrm{~h}$ of the cumulative time, duplicating the measured temperatures at $\mathbf{1 4 . 7}$ to $20 \mathrm{~h}$ of the cumulative time.

grain on concrete floor made more than a $10^{\circ} \mathrm{C}$ difference to the concrete floor temperature (Fig. 10). When the thickness of the grain was equal or less than $0.01 \mathrm{~m}$, there were no differences in the temperatures on the concrete floor in the presence and absence of grain after $15 \mathrm{~h}$ of heat treatment (Fig. 10). Brijwani et al. (2010) also found that floors covered with $0.02 \mathrm{~m}$ deep flour took 1 to $5 \mathrm{~h}$ longer to reach $50^{\circ} \mathrm{C}$ than floors with thin flour dust. The setup of the experiment was slightly different than that used in this experiment (Jian et al. 2012). The former had the flour inside a plastic box with a lid. Therefore, cleaning before heat treatments must be done to avoid residues of no more than $0.01 \mathrm{~m}$ thickness of grain or grain products on the floor.

Flourmills are usually multi-storied structures, constructed with a variety of flooring materials such as concrete, wood and metal. These materials influence the rate of heating. The ground floor is the most difficult to heat up, because concrete and soil act as enormous heat sinks. For floors that are heated on both sides, the heating will be quicker than on the ground floor where there is heat loss to the soil. Therefore, on upper floors, grain and grain product deposits of greater than a $0.01 \mathrm{~m}$ may be allowed, thus still ensuring an effective heat treatment process. Deposits of grain and grain products left in equipment serve as refuges and food for insects. The model in this experiment cannot be used to predict the amount of residues left inside equipment that would still attain sufficient temperatures to control insects. Therefore, 


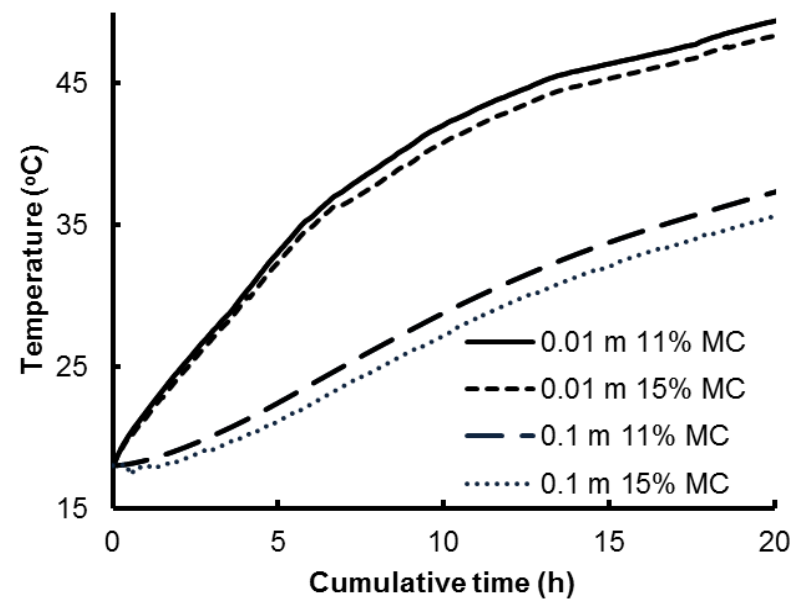

Fig. 9. Simulated temperature of the concrete floor covered by 0.01 and $0.10 \mathrm{~m}$ thickness of wheat with $11 \%$ and $15 \%$ moisture contents.

further studies would be required to make this prediction for upper floors of a building and for equipment.

\section{CONCLUSIONS}

(1) The maximum residue between the measured and predicted temperatures of the concrete floors under grain was $3.2^{\circ} \mathrm{C}$.

(2) Moisture content of the grain could make about $2.5^{\circ} \mathrm{C}$ difference to the concrete floor temperature.

(3) Cleaning before heat treatments should be sufficient to have residues of no more than $0.01 \mathrm{~m}$ thick of grain or grain products on floors.

\section{REFERENCES}

Acs, F., D.T. Mihailovic and B. Rajkovic. 1991. A coupled soil moisture and surface temperature prediction model. Journal of Applied Metrorology 30: 812-822.

Arinze, E.A., G.J. Schoenau and F.W. Bigsby. 1987. Determination of solar absorption and thermal radiative properties of some agricultural products. Transactions of the ASAE 30: 259-265.

Arpaci, V.S. and P.S. Larsen. 1984. Convection Heat Transfer. Englewood Cliffs, NJ: Prentice-Hall Inc.

ASABE. 2009. ASAE Standards ASAE D243.4 May 2003: Thermal Properties of Grain and Grain Products. St. Joseph, MI: American Society of Agricultural and Biological Engineers.

Bala, B.K. 1997. Drying and Storage of Cereal Grains. Enfield, New Hampshire: Science Publishers, Inc.

Brijwani, M., B. Subramanyam, P.W. Flinn and M. Langemeier. 2010. Structural heat treatments against Tribolium castaneum (Herbst) (Coleoptera: Tenebrionidae): effect of flour depth, life stage and floor. In Proceedings of the $10^{\text {th }}$ International Working Conference on Stored Product Protection, 622-627. Julius-Kühn-Archiv, Estoril, Protugal. June 27 - July 2 .

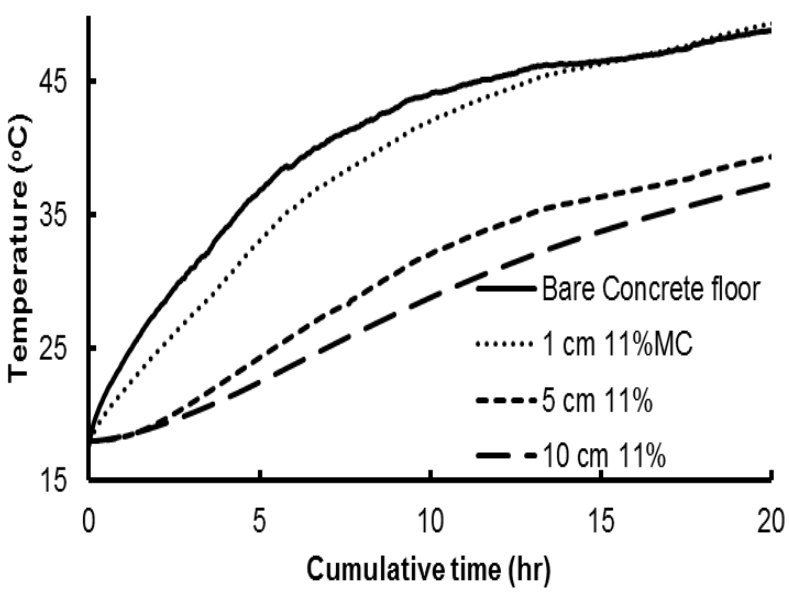

Fig. 10. Simulated temperature of the concrete floor covered by $0.01,0.05$, and $0.10 \mathrm{~m}$ thickness of wheat with $11 \%$ moisture content.

Bruce. D.M. 1985. Exposed layer oats drying: three models fitted to new data up to $150^{\circ} \mathrm{C}$. Journal of Agricultural Engineering Research 32: 337-347.

Cenkowski. S., J.T. Hong, M.G. Scanlon and S.D. Arntfield. 2004. Mathematical modeling of heat and mass transfer during continuous infrared micronization. Drying Technology 22: 2255-2272.

Crank. J. 1975. The Mathematics of Diffusion, 2nd edition. Oxford, UK: Clarendon Press.

Jayas, D.S. 1995. Mathematical modeling of heat, moisture, and gas transfer in stored grain ecosystems. In Stored-Grain Ecosystems, eds. D.S. Jayas, N. D. G. White, and W. E. Muir, 527-567. New York, NY: Marcel Dekker Inc.

Jian, F., P.G. Fields, D.S. Jayas, N.D.G. White and M. Loganathan. 2012. Measured and predicted temperatures in a grain processing building under heat treatment - 1. Temperature profiles during heat treatment. Canadian Biosystems Engineering 54: 3.13.8 .

Krarti, M. and D. Claridge. 1988. Analytical calculation procedure for underground heat loss. ASHRAE Transactions 94: 982-991.

Massie, D.R. and K.H. Norris. 1965. Spectral reflectance and transmittance properties of grain in the visible and near infrared. Transactions of the ASAE 8: 598-600.

Page, G. 1949. Factors influencing the maximum rates of airdrying shelled corn in thin layers. Unpublished M.Sc. thesis. West Lafayette, IN: Department of Agricultural Engineering, Purdue University.

Sinicio, R., W.E. Muir, D.S. Jayas and S. Cenkowski. 1995. Thin-layer drying and wetting of wheat. Postharvest Biology and Technology 5: 261-275.

Thomas, L. 1980. Fundamentals of Heat Transfer. Englewood Cliffs, NJ: Prentice-Hall, INC. 
Thorpe, G. 2002. Ambient air properties in aeration. In The Mechanics and Physics of Modern Grain Aeration Management, eds. S. Navarro, and R. Noyes, 79-123. New York, NY: CRC Press.

\section{LIST OF SYMBOLS}

CE convective energy exchange between air and the grain surface $\left(\mathrm{W} / \mathrm{m}^{2}\right)$

$\mathrm{D}_{\mathrm{m}} \quad$ coefficient of diffusion $\left(\mathrm{m}^{2} / \mathrm{s}\right)$

$\bar{h}$ the average convective coefficient of the heat transfer at the concrete or grain surface $\left(\mathrm{W} /\left(\mathrm{m}^{2}\right.\right.$. ${ }^{\circ} \mathrm{C}$ )

$\mathrm{k}_{\mathrm{a}} \quad$ thermal conductivity of the air $\left(\mathrm{W} / \mathrm{m}{ }^{\circ} \mathrm{C}\right)$

$\mathrm{k}_{\mathrm{g}}$ thermal conductivity of the grain $\left(\mathrm{W} / \mathrm{m}^{\circ} \mathrm{C}\right)$

$\mathrm{L}$ distance from the fan to the pile of the grains (14.6 $\mathrm{m})$

LE latent heat exchange between the grain and the air $\left(\mathrm{W} / \mathrm{m}^{2}\right)$

$\mathrm{L}_{\mathrm{g}} \quad$ latent heat of the grain $(\mathrm{J} / \mathrm{kg})$

$\mathrm{M}_{\mathrm{d}} \quad$ grain moisture content (dry basis, decimal)

$\mathrm{M}_{\mathrm{e}} \quad$ equilibrium moisture content of grain, $\mathrm{db}$

$\mathrm{M}_{0} \quad$ initial moisture content, $\mathrm{db}$

$\mathrm{M}(0, \mathrm{t})$ moisture content of the top layer at time $\mathrm{t}, \mathrm{db}$
Pr Prandtl number (0.708)

Re Reynolds number

RE radiation energy exchange between the building ceiling and the grain surface $(\mathrm{W} / \mathrm{m} 2)$

$\mathrm{RH}$ relative humidity

$\mathrm{s} \quad$ total thickness of the grain mass (m)

$\mathrm{T}$ temperature of the materials $\left(\mathrm{K}\right.$ or $\left.{ }^{\circ} \mathrm{C}\right)$

$\mathrm{T}_{\mathrm{c}} \quad$ temperature of the building ceiling $(\mathrm{K})$

$\mathrm{T}_{\mathrm{s}} \quad$ temperature on the grain surface $\left({ }^{\circ} \mathrm{C}\right)$

$T_{\infty} \quad$ measured air temperature at $0.05 \mathrm{~m}$ above the concrete floor $\left({ }^{\circ} \mathrm{C}\right)$

$\mathrm{t}$ time (s)

$U_{\infty} \quad$ air velocity $(\mathrm{m} / \mathrm{s})$

$\mathrm{x}$ distance between two measured temperature locations in the horizontal direction $(\mathrm{m})$

$\mathrm{Z} \quad$ depth of the grain, concrete, and soil in the vertical direction $(\mathrm{z}=0$ at the surface of the floor or grain mass) (m)

$\alpha \quad$ thermal diffusivity of the materials $\left(\mathrm{m}^{2} / \mathrm{s}\right)$.

$v \quad$ kinematic viscosity of the air $\left(\mathrm{m}^{2} / \mathrm{s}\right)$

$\sigma \quad$ Stefan-Boltzmann constant $\left(5.670 \times 10-8 \mathrm{~W} /\left(\mathrm{m}^{2}\right.\right.$ $\left.\mathrm{K}^{4}\right)$ )

$\varepsilon_{\mathrm{c}} \quad$ emissivity of the building ceiling

$\varepsilon_{\mathrm{s}} \quad$ emissivity of the floor 